\title{
St. Denis, the Caddo and Others: Letters from Patty Lemee
}

\section{Patty Lemee}

Unknown

Follow this and additional works at: https://scholarworks.sfasu.edu/ita

Part of the American Material Culture Commons, Archaeological Anthropology Commons, Environmental Studies Commons, Other American Studies Commons, Other Arts and Humanities Commons, Other History of Art, Architecture, and Archaeology Commons, and the United States History Commons

Tell us how this article helped you.

This Article is brought to you for free and open access by the Center for Regional Heritage Research at SFA ScholarWorks. It has been accepted for inclusion in Index of Texas Archaeology: Open Access Gray Literature from the Lone Star State by an authorized editor of SFA ScholarWorks. For more information, please contact cdsscholarworks@sfasu.edu. 


\section{St. Denis, the Caddo and Others: Letters from Patty Lemee \\ Creative Commons License \\ (c) $($ ) $(9)$}

This work is licensed under a Creative Commons Attribution-NonCommercial 4.0 International License 


\section{ST. Denis, THE CADdo AND OTHERS: LETTERS FRom PATTY LEMÉE}

\section{Patty Lemée}

There we were, sailing south along the California coastline at the very top of the Princess Line's Love Boat after climbing stairs we probably shouldn't have been climbing. But there were no warning signs, and we were just young enough and foolish enough that we didn't think twice about climbing them. The winds were dangerously strong so we kept a tight grip on the railing and, altogether and simultaneously, we looked up. Awestruck. We were awestruck. No moonlight. Just that gloriously brilliant Milky Way against a pitch black midnight sky.

On a bitterly cold, clear winter night in Wilbarger County, Texas, where I grew up, the Milky Way was no casual thing to see, but it was a different Milky Way that mesmerized us that night, or so it seemed. You'd have thought Tom Sawyer himself had loaded his brush and, in one seismically forceful stroke, slathered the sky with whitewash--so thick and so near you'd swear you could smell it. It felt as if we were in the Milky Way.

I'm unprepared to say the event was a religious experience, but most certainly it was a life changing experience. I knew it instantly. I didn't know WHAT had changed, or how. As Pogo would say, those answers would require a full box of pencils and a whole lot of figuring.

Our little group of six silently descended the stairs. We didn't even say good-night to each other ... we just quietly walked to our rooms. I wondered what else about this glorious universe might I better appreciate if only I were to do so simple a thing as change my perspective. Over the years, I recognized an increased interest in other perspectives. It was those perspectives that helped me understand all sorts of things. Sometimes we need zoom lenses and other times we need wide angled ones. That was years ago and since then I've been busy considering, actually seeking new perspectives.

Just a reminder, I'm a researcher not formally trained in any "ology" typically associated with studies of "things historical and colonial." What interested me was Daddy, and he was interested in people who lived centuries ago in the area we lived, a bit south of the Red and Pease Rivers - Comanche and Wichita Indian country. I'll write more later this about those interests.

Take care,

Patty 
At the outset of this letter, let me share some additional "Milky Way" thoughts. Over the years I've related that story to several people who, it turns out, had similar experiences. In most all cases, the outcomes were similar: a realization that, in ways large and small and forever beyond our grasp or understanding, we were linked to centuries of people on Earth before us, as we would be linked to those who would be here after us. Turns out the world really wasn't about our individual selves and, turns out \#2, vantage points were as critical to understanding than were wide angle and zoom lenses.

So, wow - that put a whole different spin on things!

Fast forward with my research. I had just enough experience in business development to recognize there was some kind of recurring business activity between the French and Spanish. Bear in mind, I didn't know squat about the internet when my research began, and it's just as well because (a) I didn't know how to use a computer and (b) there wasn't anything much to find that interested me. Somebody suggested I check out the old Barker library at UT Austin. There was a "bigger picture" that included Caddo who were waltzing across Texas and other areas of the country for centuries before Europeans showed up, and when the Caddo weren't waltzing, they were trading or hunting or fishing or planting. Trading and diplomacy — Pete Gregory told me his studies revealed the Caddo had used diplomacy and trade to maintain control since at least 900 A.D. At least that's how I remember what he said. If that's wrong, it's "my bad." I was beginning to have nano glimpses understanding about how the Caddo became dominant traders across a huge chunk of real estate.

A few centuries later, along comes St. Denis from Natchitoches via French Canada. The Caddo played nice with him and vice versa. Tattoo or no tattoo, the Caddo soon recognized St. Denis as one of their own. French and Spanish colonial authorities included mention about that in various of their documents.

For now, think of the St. Denis/Ramon/Caddo and allies trade as a sport-let's say football. St. Denis is the quarterback - the play caller, the decision maker, the guy who hits his target while his eyes continuously scan the entire field. The guy who keeps the owners happy. Ramon? He is the offensive receiver so he knows in advance what's expected of him when he receives the ball. His eyes, too, scan the field, always ready with one hand waiting to receive whatever St. Denis sends downfield and ready to mix it up if something unexpected happens.

Say what?! How can this analogy work? It works only when it's recognized the game is played solely for commercial purposes, and is accomplished by members of what I once defined as "a familial trade cartel." The primary players got themselves related when St. Denis married Manuela Sanchez Navarro, Diego Ramon's step-granddaughter. So where do the Caddos come into play (no pun intended)? They and their allies control most everything except the Apaches. The Caddo are the official team owners. They have some investors who would and could assemble Jack be Nimble quick if somebody attempted to interrupt this non-spectator game.

Remember, the Caddos, recognized St. Denis as theirs. More than that, it seems . . . they seem to have adopted him. How much Ramon understood is unclear; in time, and a pretty brief time, it was clear he understood enough. Ramon was a smart man, had his own reasons for wanting to "play ball" and was happy to be in the game. The French were happy he was, too. It was a business deal. Everybody benefitted 'til some of them what weren't in the game started squawking. Imagine my surprise to conclude it was the Caddo groups, aided by their allies who controlled movement of colonial trade. The Caddo didn't rule by might; it was that diplomacy and trade thing Pete told me.

St. Denis understood and played by the Caddo's rules plus he gave them trade items they needed and wanted. In return, St. Denis was regarded as an ally who got what he requested, and that included at least safe passage for Frenchmen and Spaniards of the St. Denis and Ramon families and their pals between Mexico and Louisiana. 
Ramon or St. Denis — which of the two could jump higher, run farther . . which was the bigger, badder man? Ya' get right down to it, that's not the point. Possibly I've told you my daddy hammered away that it was more important to know less and understand more than the reverse. There are aspects - most aspects of the Ramon/St. Denis/Caddo arrangement we don't know, and probably never will. Regardless, I keep chipping away at it.

I've come to some understanding of the relationship between these men, both Europeans, each from different operating systems.

The historic record makes clear neither Ramon nor St. Denis had sons who quite measured up to their fathers' successes. One of St. Denis's sons had pretty good success as a trader, and, again, that in large measure because he was St. Denis's son and he honored the old agreements with the Caddo who, with their allies, deferred to the presence of St. Denis through his sons, grandsons and sons-in-law. Several documents make that patently clear.

Domingo Ramon officially commanded the 1716 expedition to east Texas. St. Denis was with that expedition, leaving with his Caddo guide somewhere around Cibolo Creek, reaching the Caddo to announce approach of the Spaniards. It's difficult to imagine the Caddo didn't already know who was coming and when they would show up - remember those smoke signals? I'll write more about that later. For now I'll mention only that sometimes what's NOT written in a document is equally or more important that what IS written.

Under Aguayo's orders, Domingo Ramon later did occupy Lasalle's old post on Garcitas Creek on the Texas coast, but it was Aquayo as governor who had authority to establish the site formally which is another way for the king to get credit, and kings do so like getting credit . Other Spaniards had been there before Ramon. Francisco Martinez (formerly stationed at San Juan Bautista and, later, Pensacola) twice had gone to the site - argh ... I cannot remember which expedition leader mentioned that. Maybe Salinas Varona. Yes, it was Salinas Varona! Regardless, a storehouse had been built at the old site for goods being shipped there for delivery to Caddo groups in east Texas.

Okay, that's it for now. I've gotta' get some sleep and tomorrow tell you some things I learned about the effects of the War of the Quadruple Alliance. I make no claim that my understandings are the $5^{\text {th }}$ gospel. I claim only I haven't poached anybody else's work. If you benefit from something here, and can use it to move the wagon even a "smidgen" down the road-excuse me, down the camino, well, that's a good thing.

Happy trails,

Patty 
Just a bit more about this trade business. If you've not read Iberville's Gulf Journal, get a copy, sit back, read and prepare to be amazed. Iberville, while on his first voyage, wrote about five Spaniards who had deserted Pensacola. Those five encountered some Mobile Indians who brought them to Iberville. One of the five advised Iberville (1) there was at Pensacola a Spanish soldier and maker of edge-tools who previously had been among those who went to drive out Lasalle on the gulf and to seize the rest of his people and (2) that same Spaniard had chosen to live in a fort in an Indian nation for three years. Seems they didn't get along with the Indians and were forced to abandon the area, leaving two cannons at the site. The five claimed that from that place to Mexico there is a good trail, over which they intended to follow on the return to Mexico. Reportedly two of Lasalle's Frenchmen had married among these Indians. Iberville believed the Indians were the Senys (variant of Hasinai.) Bingo!

It was in that conversation that Iberville first realized how to reach the Hasinai where he could find and hire Caddo guides to lead Frenchmen to the Spaniards in Mexico and to the wealth of their silver mines. I have no clue what the French colonial equivalent of the Happy Dance is, or a high five for that matter, but ya' gotta' believe Iberville was doing some high stepping! All Iberville knew before that encounter was contained in his copy of Joutel's journal of Lasalle's gulf expedition, the contents of which predated establishment of Spanish missions in east Texas. How I would like to have seen Iberville's face when he realized that! I read the passage several times over several years before I snapped to about that entry. From time to time we all "read over" things and then suddenly there's that "Milky Way moment" and zhazam! In short order, Iberville left Mobile and was underway to Louis XIV's court in France with information Iberville believed surely would persuade the Sun King to recognize formally and to provide well for Louisiana as a French colony. Iberville's beliefs became reality. Soon after, sails were unfurled; Iberville and Co. were Louisiana bound, a second time.

In his journal for the second voyage, Iberville wrote that he "had no need to take naval cadets into the woods or a good many of the others, who are not at all suited for such; I brought them along only to go to the Nadches." In other words, Iberville wanted only French Canadians experienced in Indian relations to do the "heavy lifting," among them his cousin and his uncle by marriage, Louis Juchereau de St. Denis.

Now, how cool is THAT?! It could be argued successfully and easily so, that Iberville brought St. Denis to Louisiana specifically to make the overland trip into Spanish territory. The trip was delayed by some 13 or 14 years because of the deaths of Iberville and Louis XIV, but it finally happened in 1714, when St. Denis first waltzed across what eventually became Texas.

Be well,

Patty 
The holidays seem to come around faster this year. I won't say I'm old, but the future surely is a lot closer than it usta' be. :-)

For the life of me, I don't know how it happened but at some point I found myself knee-deep in Europe's War of the Quadruple Alliance and how that played out with French/Spanish/English relations in this part of creation. And there are "pirates a'plenty" as well. Honestly, it's another in a list of things that found me and wouldn't let me go, thankfully. What triggered my interest in the matter was Pena's diario of the 1721 Aguayo entrada into Texas - not the whole thing, but a few inclusions I didn't understand. Things like Aguayo's instructions to leave some sign for the Apaches ... say WHAT? The Apaches already were consistently raiding San Antonio. Why in the world would you leave them signs about anything for the Apaches?! (Yes, I did figure out that one and will tell you later in the Holy Moses, hang on to your hat section!)

December 24, 1718, Mr. Secretary Craggs at Whitehall (England,) prepared a circular letter to Governors of Plantations, notifying them that on Tuesday, December 16 of that year, a Council was held at St. James (Palace). At that Council, His Royal Majesty had signed a Declaration of War against Spain. The Regent agreed the same Declaration of War should be made in the name of the French King at Paris.

Also on December 24, 1718, at Nassau on Providence, Bahama Islands, Governor Woods Rogers, former sea captain and privateer, prepared a letter for Mr. Secretary Craggs, informing him word of Sir George Byng's success in the Mediterranean had reached Nassau. That news persuaded Rogers the war either was proclaimed or "on foot." The pace quickened, some places and some paces quicker than others.

For considerable time, authorities in Charlesfort and the Bahamas had petitioned for immediate aid. Rumors of Spanish assault at both locations intensified. As it happened, news of the war first reached Bienville at Mobile. That precipitated the French attack and capture of Pensacola. Afterward, Spanish prisoners of war were gathered up, packed on vessels and sailed to Havana. At exactly that time, a rag-tag Spanish mosquito fleet was outbound, headed to assault first Charlesfort (Charleston) and then to the Bahamas, when the vessel from Pensacola was spotted entering Havana harbor. Almost immediately, things were topsy turvy and voila, the French were imprisoned!

Gotta' tell you, the info about Charlesfort and the Bahamas was a real surprise for me. I knew only about activities in Pensacola and the so-called Chicken War at Los Adaes. I think I remember asking around for information about any other hostilities in what's now the United States resulting from the war in Europe. Either I asked the wrong people, or folks I asked didn't know, either. Best sources I've found are Barcia's History of Florida and a dandy series of books I stumbled over titled Series of State Papers, in particular the books noted "America and West Indies." Barcia's history was sent in CD format from a friend in Florida, and, concerning the book series, my "stumbling" this time was done at UT's PCL. I was giddy as a schoolgirl for weeks! In those books I found answers to questions I previously had not known to ask!

Authorities in Havana knew the English had declared war against Spain, but they had no knowledge the French had, too, at least not until the Spaniards got the news at Havana from which place word of the French Declaration of War was taken to Vera Cruz. Before I get ahead of myself, would you believe it was Mobile Frenchmen who hand delivered news of the war when they hand-delivered to Havana prisoners from the captured Pensacola? Well, seems the folks at Havana did not take the news well so they did some "prison-taking" of their own.

Admiral Byng's assault had far-reaching effects which resulted in there being fewer than the usual number of vessels in Vera Cruz. Thus, the response from Mexico was slower than otherwise it might have been to attack the French then 
holding Pensacola. Spaniards did attack and reclaim Pensacola, and kept it just long enough to get things around there somewhat tidy when darned if the French didn't show up to return the favor. France retained Pensacola and kept it until after the war's conclusion and treaties signed. France really, really wanted to keep it, and Spain really, really wanted it for themselves. These letters I'm writing are, for me, a super way for my telling this story - it gives me the wiggle room I need to jump from the Atlantic Coast to the Pacific Coast of our United States, and to sail back and forth across oceans and gulfs. And, truth be told, I'm having a second go at all the fun over the years when I'd find a tidbit here, another there.

Let's look now at St. Denis who, in 1719, has escaped prison, reportedly in Mexico City, made his way up and across the Rio Grande and is traveling northeastward toward the Louisiana colony. Talk about good timing! I think it's more than amusing to recognize that about the same time St. Denis had gotten through what we know today as San Antonio, Coahuila governor Martin de Alarcon was traveling the same direction but couldn't get much beyond there; seems the Indians of Rancheria Grande stopped him. Alarcon's men inquired of a group of Rancheria Grande, I think it was the Sana, whether St. Denis had been spotted in the area. Well, yes he had, they said, but he didn't have anything to trade so they let him go through. At least the Ervipiame and some other groups of Rancheria Grande by that time were allies of the Tejas, and, by extension, allies of the French, but definitely not allies of the Spaniards.

Leaving Mexico, Rancheria Grande had left their Rio Grande/northern Mexico haunts by 1716, eventually ranging between the Colorado and a bit eastward of the Brazos. Even found them once or twice near the Trinity and that was Caddo country. Viceprefect Miguel Sevillano Paredes' 1727 description of the Sana, a group within Rancheria Grande, places them at Navisi. Pretty fun stuff, huh? Probably Alarcon didn't think it was a bit funny and I'm guessing authorities in Mexico didn't think so either. St. Denis made it back to Mobile via Natchitoches in time to participate in the French recapture of Pensacola. And Alarcon got back to Mexico in time to get his pink slip. Aguayo replaced Alarcon.

This is as good a place as any, I suppose, to mention I disagree with Newcomb about the Ervipiame being Tonkawa originally. I don't dispute the groups may have coalesced at some point later in the $18^{\text {th }}$-century, but there's zero in the record that I've found to support the Ervipiame originally were Tonkawa. Over the years I've collected a big binderful of copied documents about the Ervipiame and Rancheria Grande; not one mention of the Tonkawa in any of them. Father Paredes, after relocating from northern Mexico to the San Antonio mission Valero where he served also as President of the Missions described the Ervipiame in the mid to late $17^{\text {th }}$ century as being among the corsarios naciones who continually raided the roads from the Rio Grande to Zacatecas, killing Spaniards, mission priests, mission livestock. Scant as the record is, it's clear the Ervipiame were old enemies of the Apache, and no friends of the Spaniards. By the time of Domingo Ramon's 1716 expedition, the Ervipiame were allied with the Tejas and were armed with French weapons.

Ramon 1716 diario into Texas states he recognized one Ervipiame in particular, describing him as "someone who has done us harm in the past." By the late $17^{\text {th }}$ century, there are Ervipiame who were Rancheria Grande, allies of the Caddo long before relocating north of the Rio Grande, later were referenced in various documents as encadenado. Indeed, the groups were linked, and sometimes impenetrable, as Alarcon had learned. Later, when Aguayo's expedition traveled through Rancheria Grande territory, Pena, the diarist, specifically mentioned Aguayo issued orders their fields be crossed carefully so crops would not be damaged. Aguayo wasn't stupid.

I'll write again soon.

Peace.

Patty 
How many times I read Pena's account of Aguayo's 1721 expedition, I can't be sure, but each time for a different reason. Between readings, I'd read other things which explains why with each reading of Pena, I'd find something that had not registered with me previously. This particular time, which happened to be after I'd turned off the lights for the night, I thought of something he had written that I realized I didn't understand so I just HAD to get out of my toasty warm bed, grab my copy of Pena and read that passage again ... right that red hot minute. Well, I found multiple "something's." I spent the next few years researching the Aquayo expedition and the War of the Quadruple Alliance.

Oh, gotta' side-step here ... there are a couple of really interesting things I failed to mention. I'm as much a critic of Pichardo as the next person when it comes to his opinions; however, the man did gather and publish some really esoteric documents that are worth reading. The first, as I recall, is reported in each of the four volumes. Governor Barrios, in a letter to the viceroy, wrote that the Caddo all say the Spaniards give them fair words but the French give them fair words and presents. That's one of my favorite quotes ever. I've passed it along to only a couple of people over the years, but saved it for use in something I might write, and this is it.

I don't remember what order this all unraveled. Sorry. Don't even remember all the sources; my books and papers now are in the archives in Natchitoches. A good many things I still have here in Austin.

I truly appreciate what might read like a ride on a roller coaster- full of ups and downs and zig zags. But that how life unfolds, isn't it? Once I got into my research, I had to go where it took me, and that's how I write it—zoom lens for a minute and then a wide angle and, sometimes, for me, it's like watching an I-Max movie. So, thanks again for allowing me the twists and turns-it's how I came to my understanding about Frenchmen and Spaniards and Caddo and other groups that go bump in the night.

Pichardo's four volumes include quotation of multiple documents, several referencing the Marques de Aguayo's knowledge that Spaniards had captured a French vessel in the Gulf. By other sources I figured out that vessel was the Aurore, formerly a slaver that had been outfitted with armament at St. Domingue (formerly French-held side of modern Haiti.) The most important thing aboard that vessel was a set of French plans of invasion of Mexico.

The Pichardo documents state the viceroy and auditor in Mexico knew about the impending French invasion; there is mention that notification was sent to the king and to Aguayo as he prepared for his 1721 expedition to invade and eliminate the French. Other sources made clear the alarm had been sounded to Spanish authorities far and wide. I'll tell you about that later.

Back to the plan which specified St. Denis as leader of the ground forces. He was to march south to Lasalle's old post to meet naval forces commanded by Iberville's brother. From there, they were to proceed to the mouth of the Rio Grande and then see how far it could be navigated, hopefully to the far as Minas de San Gregorio at modern Candela. Derbanne from Natchitoches had visited those mines a couple of years prior and the location was known to St. Denis.

So it's little wonder that Aguayo, still south of the Rio Grande when he learned from Sana Indian guides that St. Denis was gathered with Indian allies near or on the Brazos River, above the road to the Tejas, gave orders that Domingo Ramon immediately leave a fledging San Antonio de Béxar to occupy the former site of Lasalle's old post. Was there a duplicate set of plans sent to the colony from the French court? Can't say for sure, but this most recent news about St. Denis surely made Aguayo wonder as well. As if that weren't enough stress for the marques, how about all those "yes," "no," "do," "don't" orders from the viceroy to Aguayo about attacking the French?

Matters on the frontier suddenly became more like bumper cars at the state fair midway than like the slower paced but continuously in motion lava lamp globs - you couldn't go very far before some other car rammed into you, stopping your forward movement altogether or turning your car in the reverse direction. Everybody's crashing into everybody else. 
Whether St. Denis had met Aguayo in Mexico is unknown, but certainly each knew about the other. In this circumstance, Aguayo surely believed he had the advantage with foreknowledge of French intentions. Oh, did I mention after Ramon left the east Texas missions, he was ordered to the Mexican interior where he spent several months enlisting recruits? If he didn't know before, Ramon would learn he and those he recruited would be unwelcome neighbors at La Bahia. What a surprise when Aguayo later showed up with his recruits who signed on with better benefits packages than Ramon's recruits. Now there's an "opps moment" for you!

Patty

Back to Pena's account. He referenced a Monsiuer Rerenor at the Los Adaes site. He also identified St. Denis as commander of the forces on that entire frontier. Interesting. Rerenor actually was Renault d'Hauterive who had arrived Louisiana in 1720. He quickly was commissioned captain in command at Natchitoches, replacing the deceased Blondel.

Benard de La Harpe notes Bienville received from Renault word of Aguayo's arrival at Los Adaes. La Harpe wrote that the news raised Bienville's concern the French at Natchitoches might be overpowered. Bienville was afraid if that occurred, he personally would be blamed for not having given the command to St. Denis who had great influence over the Indian nations. La Harpe records that Bienville thus decided, against his will, to have St. Denis relieve Renault. There was nothing obscure about Bienville's animosity toward St. Denis.

With knowledge that Renault and not St. Denis commanded for a year and a half after Blondel's death, a new question pops up: where was St. Denis during all that time? Two documents written, in Paris, offer clues. The first document, dated July 1, 1720, gives command of the haute Rivière aux Cannes to St. Denis. The location of the command is puzzling because it's unclear what modern river the French authorities in Paris in 1720 recognized as Riviere aux Cannes. Modern Cane River in Louisiana, a channel of Red River in lower Natchitoches Parish, is a mid $18^{\text {th }}$ century river name which first appears in the historic record after St. Denis's death. So, the 1720 reference suggests it was some river other than the Red.

Turns out there's another "vantage point" or reference to Rivière aux Cannes that does appear in the journal of Henri Joutel who recorded La Salle's 1684 Gulf Coast expedition. Joutel used the name when referring to the combined Lavaca and Navidad rivers in Texas. Delisle's 1718 map of the region identified Rivière aux Cannes as the lower portion of a river he designated upriver as the Río San Marcos or Colorado, today recognized as the Colorado River in Texas. Considering French interest in occupying La Salle's bay and the Crown's plans to penetrate the Spanish mining country, coupled with St. Denis's other known activities, it is reasonable to suggest St. Denis was assigned command of a region in Texas.

The second document, dated September 27, 1721, mentions St. Denis as post commander without a company at an annual salary of 1,800 livres. Hmmmm ... was he truly "commander of forces on the entire frontier," as Pena had written, including, from the French perspective, all the known area of Texas? There is evidence St. Denis's "forces" were Indian groups allied to him through trade - Indian groups he had convened to attack the Spaniards, that is before Aguayo showed up. How fun! How cool! 
A third document describes the site was a trading post or what was to have been a trading post. It's unclear whether it ever were built. How interesting - a French trading post deep in the heart of modern Texas! He was to have had a partner, Jean-Francois Willart d'Auvilliers, but colonial authorities in France squashed that idea. Seems Dauvilliers previously had been to Louisiana with the Mezieres concession. His duties completed on that first expedition, the guy sails back to France and receives his commission as St. Denis's partner at the trading post. These documents were issued within a couple of days of LaHarpe's receiving his commission as commander of LaSalle's old post on the coast. Dauvilliers, or "Gabby" as we can call him, ended up in a Parisian pokey after telling people the John Law Company was a scam, that he personally had been to Louisiana and it was NOT the land of milk and honey, as described by Law's agents. Thus, Dauvilliers's return to Louisiana was a no-go. Later, in 1744, members of his family sued for what they contended were lost wages per the contract with their ancestor. Tip o' the hat to Francois Lagarde, Ph.D., UT Austin, who located the document for me in Paris, and did an Evelyn Woods "speed translation" for me. I'm indebted to him.

Turns out that crafting the peace treaty concluding the War of the Quadruple Alliance took almost longer than the war itself! Negotiants met in Madrid, at Cambrai, in London ... meeting after meeting in which nothing was accomplished beyond a lot of $18^{\text {th }}$-century posturing. The bone of contention turned out to be Pensacola. The French didn't want to give it up. They'd twice captured her and they intended to keep her! But Spain wouldn't agree to it. It made no sense, really ... in multiple ways the French were better positioned than Spain to defend it. Mostly, the French just wanted the Spaniards gone. They wanted especially control of the harbor, the coast, and the mouth of the Mississippi River. But Pez wouldn't budge on Pensacola nor would Philip V budge on Gibraltar.

Over the years, I've done a little crafting and negotiating on a vastly smaller scale, but sufficient to know negotiations concluding most things are accomplished quietly and the main points held sub-rosa. Took a while, but I found themat least enough to address questions I had about the 1721 expedition and about how the War of the Quadruple Alliance played out elsewhere.

This whole project was such fun. I'd read passages and laugh aloud all by myself. It's known Aguayo made numerous "tweakings" of Pena's diario, sort of "colonial airbrushing" to present the governorship in the best possible light.

As for that airbrushing, it reminds me of the painting supposedly depicting the Villasur massacre a bit west of Tejas country, but linked to it. Killed in the Villasur massacre was Jean or, by then, Juan L'Archeveque who formerly was with the Lasalle expedition. The artist, in an attempt to defend the defeated commander, covered the canvas with tiny French soldiers declaring, in effect, "See, Mr. Viceroy, it wasn't our fault. Really. We were outnumbered and outgunned."

Patty 
So let's rejoin the "negotiations," and I use the term loosely to describe what occurred at Cambrai, France. Gotta' tell you, diplomacy hasn't changed much through the years. If you can tolerate it, tune in to any television news program to see what I mean. One negotiant there was called "Goatface." To his face the man was called Goatface! Since then and now, we have managed to get ourselves to the moon and safely home again, but we have made zero progress in playing well together! It isn't lost on me, or others, that the Caddo groups were superb "getter along-ers." We might do well to follow their example.

Among the Cambrai negotiants for the English were Robert Walpole, Stanhope, and Jean-Francois Langeron de Maulevrier for the French. One of the negotiants personally knew Andres de Pez. Maulevrier requested that person to have a little chat with Pez. Didn't go well. Story went like this, and the story came to me in a book that was a chronology of communications between the various negotiants. Can I recall the title? No, I can't. But I found it in a book, a very old book and very tiny old book at PCL. It'll pop up sooner or later and I'll send to you. It's in PCL which puts you WAY ahead of where I was when I found it. Seems Philip V wanted Gibraltar, which he got, sorta' kinda' but not really. Actually, not at all, but he thought he did. The king didn't care about much else, and "much else" included Pensacola but by that point he was hiding his own Easter eggs if you get my drift so it didn't really matter. But it did matter to Andres de Pez? Remember him? Turns out the man had become his Majesty Philip V's top advisor, the same man whose father and brother had been slain by the French in a naval battle, the man who was court-martialed because French privateers captured the Talon children (they had been with Lasalle's gulf expedition, captured by Alonso de Leon for delivery to the viceroy who ordered, eventually, they be transported to Spain's Philip V.) Pez commanded the Windward Fleet and the children were aboard one of those vessels when the French showed up, recaptured the children and whisked them back to France just in time to hop on another Louisiana-bound vessel commanded by Iberville. Just three centuries and change shy of the first "travel rewards program." Bummer. Pezthe man denied the right to establish a settlement at Pensacola, a site he had selected? THAT Andres de Pez! Records make pretty clear the man despised the French, and he still clug to the rebuff at being denied command at Pensacola. Pez would not be denied Pensacola again, and this time he was positioned to ensure that outcome.

It's been generally reported that "Cinco" already was losing his mental grip at a time when Pez was the king's confidant and chief advisor and at the top of his game. Whatever else Pez wanted, and he wanted Pensacola, Philip would approve. Maulevier was told Pez wanted Pensacola as much as Philip wanted Gibraltar, and that's what was required to conclude the Cambrai effort to end the war. Maulevrier had no choice but to return Pensacola to Spain.

Before continuing, let's talk about Pez some more.

Eventually exonerated of the "Talon Incident" as I call it, Pez was promoted and served two years as captain-general of the Indies fleet. In 1715, the commander was received as a member of Spain's Supreme War Council. Two years later he was governor of the Council of the Indies and in 1721, was secretary of state and navy. Pez was considered to be His Majesty Philip V's most trusted advisor. THAT explains how Pez had serious clout at court when negotiating a treaty to conclude the War of the Quadruple Alliance.

Oh, yes, another part of the deal was that Spain got to keep all her positions established west of the Sabine River; Spanish Texas emerged from Pez's demands at the Congress of Cambrai. Period. And THAT explains how exactly Spain kept Pensacola and how Spanish Texas emerged. It wasn't Spanish superiority under Aguayo's leadership nor French ineptitude under St. Denis that determined the future of what became Texas. That's a departure from what we too long have been taught about the emergence of Spanish Texas. I knew Spain kept Pensacola - shoot, we all knew that. I just didn't know how exactly. It's those little details that keep all these documents interesting after reading each of them bajillions of times until we attain some modicum of understanding. Reading and rereading, and changing lenses and vantage points, looking upriver instead of down, and back again. 
Pensacola wasn't quickly returned to Spanish authorities. Maulevrier arranged continued French control as long as possible and, when the site was returned, it was in ashes, just because Maulevrier was in a position to arrange that special adios to Pez. Within days, Andres de Pez died in Spain.

My research had begun by trying to unravel Manuela Sanchez Navarro's genealogical trotline. She was St. Denis's wife, remember? 'Twas a long way 'round the mulberry bush to complete the work, but I kept at it because I believed, and correctly so, that her exact identity and extended genealogy had direct bearing the trade relationship between her husband and her own relatives, and they with the Caddo. I'm glad I stayed with it.

From time to time, I'd wondered about when and how exactly she and their two children arrived at Natchitoches where her husband was in command. Lo and behold, it was more dumb luck than logic or skill on my part that revealed the answer. There's a document dated 05 November 1757 in the Béxar Archives. Therein is discussed information supporting the Spanish view that the homesite of Monsieur de St. Denis' son belongs to the jurisdiction of Spain. The text includes, per my notes, "In support of the belief that this territory belongs to the jurisdiction of our sovereign, Lt. Joseph Gonzales and alferez don Pedro Sierra agree in saying that when Dona Manuela Sanchez Navarro came to go to her husband, Monsieur de St. Denis, an order arrived instructing that she be taken to meet him at the place where the jurisdiction of Spain terminated and that they went with the said woman and Fernando Perez de Almasan to the banks of the Colorado (modern Red) River where the transfer was made and they turned back from this point." For anybody new to the subject, Almasan succeeded Aguayo as governor of Texas.

These "things historical" usually turn out to be exceedingly more complex than they seem when first read. Certainly more complex than I could have imagined. Sometimes, often times, the complexity arises from what is NOT mentioned in a document. There's just one thing more I want to discuss, and I'll do that in the next letter.

Take care,

Patty

Soon after starting my research long ago, I taped blank newsprint to my walls. (I didn't yet own a computer.) As I learned new bits and pieces, I scribbled them on those pages, things like who was where when, and why. Eventually, with other information, the scribblings found themselves in my computer.

I undertook an examination of how that war in Europe played out in regions far removed from there. Boy oh boy, so many Milky Way moments. I mentioned earlier a bit of what I discovered about Charlesfort (modern Charleston) and the Bahamas.

It a good thing these are simple letters and that I can, metaphorically speaking, stop the train when needed to plug in information where needed. Like right now! Think previously I'd written the Minas de San Gregorio were near Candela. Well, no they weren't - they were at Cerralvo, Nuevo Leon. It's where Derbanne visited on his 1717 trip-mentioned in his journal. He'd traveled there with St. Denis from Natchitoches. Derbanne's son later married Victoria, a daughter of Commandant Gonzales from Los Adaes.

The couple moved to San Antonio where probably a priest miswrote their name and voila! Abracadabra! Berban. Berban descendants remain in San Antonio; sadly, none surnamed Berban. Sad, too, the commandant died en route to San Antonio. Near Nacogdoches, I think. 
How best to demonstrate visually what was occurring between the empirical powers in the years before, during and after the War of the Quadruple Alliance? Until 6 or 7 years ago, what I knew about that war was limited to the various invasions of Pensacola and the "war that wasn't," the so-called Chicken War at Los Adaes. You've seen those lava lamps, right? Well, if you don't have one, get one, plug 'er in and just wait. Soon you'll see globs of goop in motion, colorful, continuous slow motion, bubbling upward. The "globs" form at the bottom of the lamp, near the heat. As those move up, they quietly collide with other globs, thus changing shapes of the original globs, creating new ones in the process. And just when that's done, here come more globs, etc., etc., etc. Everything's in motion that precipitates continuing collisions. Pink. Did I mention my globs are pink? Bright pink. Almost a neon pink. The lava lamp imagery works for me.

What next I discovered also works with the lava lamp analogy, but it's better to say it's like a lava lamp on steroids. So much, so fast. Some simultaneously, some not. And it's not one or two things simultaneously—it's multiple things simultaneously. The governor of Santa Fe is in Parral (Chihuahua, Mexico) when he receives word from the viceroy in Mexico City to spread the word muy pronto that French and English ships are en route there from the Downs (England). Consult After Coronado for this information.

This is where the bazillion comes in - about seven or eight sites scattered inland with others on the Pacific side of the Sierra Madres. It occurred to me to question how exactly did Spaniards in Parral quickly notify people in Mazatlan ASAP about anything? You don't do anything ASAP if crossing the sierras is involved, which seemed to me to be the case. One direction you would not travel is south 'cause things are soggy/muddy that time of year - it's the rainy season - and, no, I don't remember what month but I verified my hunch with some of UT Austin's best. And you probably wouldn't head north to loop around the Sierra Madres and march down the coast. (Remember, the Spaniards had just made a fast trip south - something about some really ticked off Casas Grande Indians in New Mexico. Ticked off Indian groups - a recurring theme through time, it seems $(-)$.)

I looked on every map I could find. No route no where across the sierras. Not that I could find. That's not to suggest the resources did not exist; it is to say I had no knowledge of them. A last ditch effort, I plugged in what turned out to be the right combination of descriptors (whatever words those were) and Holy Document, Batman - there it wasTopia Road. Now it was me doing the Happy Dance! I just stumbled on to it. Didn't know about Topia. Why would I? Had nothing to do with trade between Spanish Mexico and French Louisiana.

I actually got teary-eyed when I realized Frenchmen and Spaniards and Englishmen and pirates and various American Indian groups on the "right and left coasts" of the present United States, north/south and east/west routes, across the Gulf of Mexico plus the Bahamas, Cuba, Mexico and other places I cannot bring to mind right now - everybody at pretty much the same time had received messages from "faraway places about pretty much the same thing. And no cell phones! Imagine that?! No cell phones, no digital nothing. Everything, everywhere was upside down. The MOST anxious people were the Spaniards. For lots of reasons. They had reports of a French invasion across the Rio Grande, (St. Denis, remember?) rumors of thousands of invading Frenchmen associated with the Villasur Expedition, and rumors about French and English ships that would attack somewhere on the Pacific Coast or the Gulf of Mexico, with remembrances of Pensacola and Los Adaes still vivid. And let's not forget when the viceroy orders Santa Cruz to be on the watch for those ships, he ordered all unlicensed French merchants in Chihuahua to be rounded up and thrown in the calaboose. No, wait, let's not do that. Oh, well, maybe we should, just to be sure.

To top things off, somebody followed up on Santa Cruz's suggestion that Aguayo be advised to do what Santa Cruz had done ... cozy up to some Apaches who might be willing to help Spaniards wipe out the French which didn't work out so well for the Spanairds under Villasur. Aguayo's reference to the Apache could be somehow connected to Santa Cruz's suggestion. If so, either the Apache didn't show or they were deterred by a show of French arms. 
Wait — what French merchants in Chihuahua in 1720?! Reportedly some were Basque, which always diced things up a bit. Some were licensed, others were not. Basques pay zero attention to whether somebody is French or Spanish. As long as you're Basque, you've got the hottest ticket in town. Only a Basque could understand another Basque.

In the early months of my research, when I had no idea I'd find all this so fascinating and spend so many years at it, I didn't take thorough notes. ARGH!! For example, somewhere in the Barker at UT there is a magic document, I think it was written in Mobile, in which Bienville himself wrote that what the French needed to find out what really was cooking in Vera Cruz or Mexico City was to send a Basque down there. He said Basques can speak openly and publicly to each other about anything without the possibility of being understood except by another Basque.

Forgive me. I've been away from all this so long that it's really a kick in the britches to be up to my chin in the research I worked so long and hard to find and even longer to understand snippets of it. I never imagined I'd be able to write this, and wouldn't/couldn't were it not for your generosity. I'm grateful to you.

When first I located "Topia Road" online 7 or 8 years ago, there were precious few entries. Google it now and watch 'em pop up. Drs. R.C. West and Bob Parsons. Dr. West left California for Louisiana to make LSU his academic home. What fun to call Pete Gregory with news of my find, and to learn he had studied under the gentleman!

Well, I fibbed—-there's actually one additional letter to follow.

Best,

Patty

Oh, gotta' interrupt myself to mention it was Massanet's 1691 diario that included numerous Caddo names on the Rio Guadalupe in Texas. Aside from the diario, there's a really super piece about that very topic in Caminos Reales: A Tricentennial History published by Texas Department of Transportation (TXDOT). Leroy Johnson and Al McGraw prepared the article. Check out p. 127 it's noted bataconiquiyoqui is Caddo. Massanet's guide was Hasinai. It's best to read the section in the TXDOT publication. There are multiple references to other stream names which seem to be Caddo.

So the "boat" arrives with notice for the viceroy in Mexico City, requesting reimbursement for the French be returned with supplies for Pensacola's soldiers. That got an immediate response from a viceroy who was not at all inclined to incur such an expense. He was perfectly inclined to give that pleasure to Salinas Varona. In fact, he insisted on it. Oh, did I mention he sent a duplicate copy to his king? Why waste an opportunity to suck up? It was made clear to Salinas Varona his job and maybe his neck was on the line ... he would NOT pull another such stunt. Period. From that day forward, the man did some major high stepping to appease the viceroy. My favorite appeasement example is what Paul Harvey would describe as "the rest of the story." It was a couple of "tell all" letters about St. Denis sent to the viceroy, penned by none other than Salinas Varona.

Farther west from Pensacola to the San Gabriel River in Texas, and a little more than two centuries later, Drs. Kathleen Gilmore and Jim Corbin were busy excavating the San Xavier missions, where the Ervipiame had lived in the 1700's. Kathleen told me this story, but I cannot recall whether she or Jim were the guilty prankster. :) Much work needed to be finished that day and the number of visiting students was heavier than usual. Finally, with calm voice and straight face, one of the two announced, matter of factly, a smallpox epidemic in the area had killed many mission Indians. The 
children were urged to move back because there was some concern about the possibility of lingering live traces of the virus. Kathleen howled and said those kids skedaddled in record time! Great memory of our late friends.

Thanksgiving is nipping at our heels, so we need me to wrap up these letters. I'll do so by telling you about some loose ends in my research, some tied and others not. Generally they concern Rancheria Grande de los Ervipiame and, specifically, the Ervipiame, both previously mentioned elsewhere in this series.

It was early when I read something about the Ervipiame. 'Twaz a long and winding road, but FINALLY, I landed a copy of the document Bolton referenced. It was SUPPOSED to have been at Our Lady of the Lake, San Antonio, but wasn't. Seems things had been changed there ... recatalogued I was told, but the original numbering system wasn't preserved. ARGH!!! Eventually, I found it. In California. Bolton Collection.

First point: there are numerous rancherias grande; they are altogether different from what French and Spanish colonial officials recognized as Rancheria Grande de los Ervipiame which, oh by the way, has at least a zillion variant spellings. Maybe two. Fray Paredes described them (the entire rancheria) as the remains of the cosarias nation that fought from Presidio of Coahuila to Zacatecas. Other authors describe them as raiding on the roads to Parral and to Zacatecas. When they ride in one large group, they are known, Paredes wrote, as Rancheria Grande de los Ervipiame. Spanish documents referring to this rancheria write it with capitals R and G. And then there's the pesky business of some writers not using capitals $\mathrm{R}$ and $\mathrm{G}$. And then again, there are those various rancherias grande.

The earliest references I found about the Ervipiame, and the Sierras Yacatsol and Dacate were in 1675 diarios of the Larios and Bosque expedition across the Rio Grande from the Spanish presidio San Juan Bautista to what is believed to be the Anacacho Mountains located west of the Nueces and extending nearly to the area of Del Rio.

Remember I'm not an "ologist" but that wasn't required to recognize there was too long in the Handbook of Texas an erroneous explanation that the Anacacho Mountains in Uvalde County, Texas so named to honor Ana, the wife of an area rancher, Sr. Cacho. Seriously. That's been corrected in the Handbook.

There are two 1688 documents that have been useful to me ... the first I found in the MUNICIPAL archives of Saltillo (since relocated to Ramos Arispe) and the second document is here in Austin. Seems much of northern Mexico was in rebellion in 1688. Come to think about it, indigenous groups throughout Nueva Vizcaya were kicking up dust. Indians pretty much everywhere had at least two enemies: Spaniards and Apaches. Now and again, sufficient numbers of groups got up enough steam to give Spaniards the boot, i.e. the $17^{\text {th }}$ century rebellions. The Tepehuane Revolt and the Pueblo Revolt come to mind. Oh, not to forget Caddo groups in east Texas had done their share of booting, forcing Spaniards to abandon their recently established missions.

Back to the Rio Grande ... Presidial soldiers from Nuevo Leon and Coahuila were headed out to find and eliminate the rebels marauding the roads from the Rio Grande, just north of Nueva Leon and west to Parral , Monclova, and Zacatecas. That's a lot of territory. Those problems coincide with turmoil created when word reaches Spaniards about a Frenchman living across the Rio Grande in a large rancheria. Seems these groups accommodating the Frenchman caught everybody's attention. Ervipiame were among them. That was 1688.

Second document, also 1688. Spaniards offer, "Oh, please, let us build a mission for you here on the Rio Grande where you can have our protection against the Apaches." "Thank you very much but no, thanks. We are leaving now to visit our friends the Tejas and we'll come back when the weather gets cold," the Ervipiame reply. FYI, in 1700 there was established for the Ervipiame Mision de San Xavier in the Valle de San Xristobal. 
Holy cow! Whoever these Ervipiame are, they are buds with the Jumano and the Tejas and they both despise the Apaches. The document makes clear the Ervipiame know how to reach the Tejas, they have made the trip previously, and are welcome to return. In other words, by at least 1688 the Ervipiame are acquainted with the Caddo. The lava lamp is heating up again! Can't wait for you to read the document and give me your opinion.

The 1688 map associated with Alonso de Leon's "captura of Juan Jari” is attributed to Diego Ramon who later commanded at San Juan Bautista on the Rio Grande. Leon's diario does not make clear whether Ramon accompanied the expedition, and it doesn't make sense he would go. Thus, I think that makes questionable Ramon's having drawn the map attributed to him. On the top left side of the map are listed a number of Indian groups and the distance between each group and either Monclova or the Rio Grande. It's really a keen map; copy to you in time. Penned under that list are the words, “dicho Diego Ramon." That I believe. If anybody knew Indian groups, it was Diego Ramon.

It was "Old Reliable" Andre Penicault who mentioned St. Denis had been instrumental in quelling some 500 or so rebelling natives near Ramon's part of creation. It was reportedly in 1713 or 1714. I couldn't quite get my head around that one. Then I remembered St. Denis had some Caddo guides for his first expedition to Mexico, and, remember, the Caddo and the Ervipiame had interactions since at least 1688. And remember, too, the Tejas and their allies had made their power known when they kicked Spaniards out of that part of creation in 1694. Cool, huh?

Buckle up. It's about to get bumpy. So when St. Denis shows up on the Rio Grande, accompanied by four Caddo guides ... well, authorities there paid particular attention. In 1717, St. Denis makes his "declaration," and there's no better word. In effect — not literally — he said, "Hello. I'm St. Denis and these are my friends that include the Caddo." But you already know that. I believe some of you might remember the Caddo. You have spent time in Caddo country and their representatives have visited you. Oh, and let me tell you about other of my friends, some you know and some you don't know." That's when St. Denis rattles off a lengthy list of allies. It would not go well for you to tinker with me, or with my friends. St. Denis's friends by then had French weapons. And bullets. Oh yes, and horses, too. They also had each other's backs.

This is just the best fun. It's like growing pecan trees. You hope every year the trees will produce a bountiful yield. When that happens, there are all those dern pecans to shell. But that accomplished, just think about the pecan pies and banana nut bread. Yum!!

All these documents ... when first you begin. It's like Alice in Wonderland when the Chesire Cat inquires, "Where do you want to go?" You don’t know. Certainly I didn’t know, so it really didn’t matter which road I took.

Earlier, by at least 1716, when the Ramon expedition crossed the Colorado River, there they are- the Ervipiame, nestled between the Colorado and the Brazos, ranging north and south as resources dictated. They were westerm neighbors to the Tejas, got along most of the time with most of the Norteno groups, and the coastal groups as well. That was yesterday's news when Domingo Ramon's expedition reached the Colorado.

St. Denis waltzed east across Texas in 1719, probably more of a quick-step considering (1) he was hightailing it out of Mexico and (2) that the War of the Quadruple Alliance was in its infancy. His route took him smack-dab through Rancheria Grande (Ervipiame, Inc.) Governor Alarcon's diario reports that nifty piece of information. The diario makes patently clear Alarcon could not penetrate Rancheria Grande. Sometimes it takes some serious restraint not to speculate, but I do wonder whether members of Rancheria Grande might have escorted St. Denis on that escape. More succinctly, members of the Tejas. I'll address that in the next letter. 
Tick tock, tick tock. There's so much information to share, but the clock's winding down. Before that happens, I must mention that while Rancheria Grande de los Ervipiame ceased to exist by that name, it continued to be recognized for several decades. The term to describe it was "encadenado." Rolls off the tongue easier than Rancheria Grande de los Ervipiame. Spot on. The chained; the linked. Indeed those groups were chained, linked together. Their linkages expanded.

Before they crossed the Colorado, where were the Ervipiame and other groups of Rancheria Grande? I can't say for sure but I've found some nifty stuff. Took only a quarter century and a whole of Pogo's "figuring" and the kindness of friends and more than one stranger. Remember Ana Cacho, the rancher's wife? Well, I'll be darned if "she" doesn't show up on an 1822 Steven F. Austin map as "Ayacatcho," a point on a "ridge of high mountains." I'd found no other mention of Austin's reference. I bought a copy of that map for a couple of dollars at my church's resale shop. It got curiouser and curiousier. I could find also no mention of Austin's personally traveling across the Ayacatcho previously which meant somebody told him about the site and that it was important enough to Austin that he note it on his map. Austin's Ayacatcho is what today we recognize as the Anacacho Mountains west of the Nueces River. East of Ayacatcho and a bit south was the Villa de Jaen, thank you Stephen F. Austin for your 1822 map which pinpoints Ayacatcho and Villa de Jaen. The villa name also was included in Jean Louis Berlandier's Journey into Mexico, 1833, I think ... maybe 1834. If you are interested and don't have those two volumes, my copies are in the Natchitoches archives. Berlandier's spelling varies from Austin's. Austin's map preceeded Berlandier's arrival in Mexico by some four years. Wikipedia (now there's a reliable resource, for ya'!) tells us Jaen derives its name from the Arabic word khayyan meaning "crossroads of caravans." That's something to chew on. Turns out Stephen F. Austin's Jaen actually was Governor Antonio Cordero's Jaen, established in 1806.

And chew on this, too ... just a little to the southeast of Nueva Jaen is Cambalache Creek in Zavala County, Texas, sorta' kinda' between Uvalde and Carrizo Springs. I found another definition of the Spanish word cumbalachi. Means something like "flea market." Well, get out the hot sauce and let's have supper! I do believe we can say with some accuracy this was a trade route or the site of trade fairs or that one could expect to find traders in the area. The word shows up variously throughout the record ... saw it once describing a site near Grace Ecore, north of Natchitoches. The earliest reference I found was 1723 Apaches who raided the San Antonio horse herds (managed to steal 80 horses.) They traded (tienen cambalache) with Spaniards to the north. As late as 1780, the Lipan received in cambalache with Cocos and Mayeyes guns and powder.

Interesting what just one word will tell you. The facts are important, but understanding them is an altogether different matter.

Back to the Anacacho Mountains. I've been there. Didn't get out of the truck-it was summertime and the place might as well have had "rattlesnakes" painted in huge neon green capital letters. Ya' don't forget something like that. I still ask "Why?" or "How come?" In the absence of a "Mrs. Cacho," there had to be another explanation. I was pretty sure the word had something to do with rattlesnakes. It just made sense. I played around with a couple of word/sound associations but kept going back to that rattlesnake thing.

It's possible (tho' I doubt it) I'm one of the last people to figure this out. If somebody did figure it out, they didn't write about it - at least not that I could find. Here's where I thank Galen Greaser, now retired from Texas' General Land Office in Austin. He knew those Spanish colonial documents, front to back, and he shared freely what he knew. I asked him the word for rattlesnake or for something that would make the sound of rattlesnakes.

Another happy dance, another Milky Way moment. Turns out the Aztecs indeed had a percussion instrument fashioned from a dried gourd. Seems they called it, "ayacachtl." Oh my stars, I was just beside myself. And who else would 
appreciate that? It felt like a one person marching band. I was so very happy and probably nobody else would care. Argh! I certainly had fun figuring it out the right question to ask. Again, many thanks to Galen.

Occurred to me folks in Louisiana wouldn't care because they never heard of Rancheria Grande or the capture of Juan Jari from the rancheria or the Ayacatcho. And we in Texas are clueless about anything east of the Sabine River which means we are taught nothing about the Natchez War. That's just pitiful.

I'll always be thankful I stumbled on some points in the Aguayo diario. Tracking those inconsistencies was my version of attaching the wide angle lens to my camera ... it took me across a whole lot of real estate and introduced me to a few folks who influenced the history of their own and other regions of the world.

There were other references to Ayacatcho. Ayacatcho and Loma Pintada. Seems there are documents a'plenty about possible relocation of Sacramento Presidio in the Valley of Santa Rosa to Loma Pintada and to Ayacatcho. This was mid 1750s. Didn't take long to find a lovely lady in the Uvalde area who sent me copies of some topo maps of Uvalde County and, yes, there's Pinto Mountain, and Pinto Creek and its multiple "prongs." And, yes \#2, those "pinto" and references were west of the Nueces along a ridge of mountains. And, yes, I had found a document stating one of the trade items from that area was "red earth." Vermillion perhaps? I'll send you the citation when I find it.

I so hope somebody else will pick this up and pursue it. Rattlesnakes aside, there's so much more to all these stories than we know. How many Milky Way moments are there just waiting to be seen?

Merry Christmas,

Patty

I've made multiple attempts to write this letter; obviously, each found its way into the trash. I'm sending this one, regardless. I 'spect I'll never be completely finished researching. I've been at it almost a quarter century (think how long that is in dog years!) I have focused on colonial Frenchmen, Spaniards, American Indians and how and where they got along, or didn't, and why. I've had great fun, learned much, come to understand some things, and made a bunch of friends along the way. I'm hopeful my thoughts in these letters will benefit you and maybe some other researchers who follow.

Other of my letters - in fact, most of my letters to you contained facts, lots and lots of facts. Those facts-filled letters were heavy as fruitcakes. I make no claim what I write is a fifth gospel, so to speak. I do claim my conclusions are just that ... my conclusions, my interpretations of my research. I've written no fiction and acknowledge there are questions I cannot answer either because there are big gaps in the historic record and definitely in my understanding of it. My fondest hope is that my work might offer clues that will help you or somebody else. So I write this letter with a keen sense of responsibility.

I remember on St. Denis's second trip to Mexico his group was attacked. "They must have been Apaches," the diarist wrote. That's an example of things I read that stuck with me, for no apparent reason. How did the diarist know they were Apaches? He didn't tell us, so we're left to wonder or to figure it out if possible. 
Another question I've never found addressed to my satisfaction . . . actually, it's a series of questions. Here goes. Please stick with me. Who/what exactly are the Tejas, why did the Hasinai so willingly welcome new neighbors, the Ervipiame and other Indians of Rancheria Grande? For decades, documents tell us, Rancheria Grande groups showed up at Hasinai trade fairs. And trade fairs of the Texas coastal groups. Before 1716, these groups were encountered south of the Rio Grande and across the river in rancherias near the Anacacho Mountains. By 1716, Domingo Ramon's expedition encountered them. They had planted crops, seemed settled west of Caddo country, ranging north and south between the Colorado and the Brazos, south toward the coast, north to the Red River and the Nortenos there, and east beyond the Trinity among the Caddo. Ramon writes that he recognized an Ervipiame who had done them harm in the past. You bet he recognized the Ervipiame. The Ervipiame now had French firearms, and Ramon no doubt recognized those, too, tho' he didn't mention it. That's another one of those things that stand out because they are not mentioned.

How did that relocation occur and who brokered the deal and why? And what's the deal with the Ervipiame and the Sana and Rancheria Grande and their relationship with the Caddo groups? I encountered the Ervipiame early in my research. Rancheria Grande, too. They were oh, so elusive and I wanted to know about them ... they had the earmarks of being something really important.

Word reached me that someone had said, "If it were that easy to figure out, somebody smarter than she is already would have done it." That person did me a huge favor! I don't pretend to understand fully Rancheria Grande or the Ervipiame, but I've moved that wagon a bit farther down the road, at least to my satisfaction, and had great fun. Later, I wrote an article that examined Aguayo, St. Denis and Juan Rodriquez, the latter Aguayo's guide and a chief of the Sana, one of the groups within Rancheria Grande at different times and in different places. Here we are all these years later, and Rancheria Grande still holds my attention. So do other puzzles, like what was the glue between St. Denis and the Caddo? Beyond the known facts, what was the truth of that relationship that endured into the 1780s between Indian groups and St. Denis's descendants?

And what was the deal between Diego Ramon and St. Denis?

Finally, what's up with all the variant names associated with Sierras Yacatsol y Dacate?

Possibly it's occurred to you I'm a systems person. How things work - that's what interests me. For the French, it was about commerce. Not so for the Spanish. They came to occupy and control everything and everybody. And that's how there came to be a whole lot of rebellious Indians. Have you read Historical Documents relating to New Mexico, Nueva Vizcaya and Approaches Thereto, to 1773? If not, do so when you can. Did it open my eyes to new perspectives about the Caddo and their interactions with other groups? You bet it did! There's lots of info about interactions of a whole bunch of folks along an east/west corridor along the Texas gulf coast to Parral, Chihuahua. Look at your map - that's one humongous stretch of land.

The book includes transcriptions of documents about La Salle \& Co., the capture of Jean Jari, believed to have been with La Salle, from a large rancheria in the Sierra Yacatsol y Dacate (today's Anacacho, a corruption of Ayacatcho.) I'm thinking at least one or two of the names associated with the sierras actually are names of individual peaks, such as they were. From those documents we learn that groups make their rounds to annual "fairs" on the Texas gulf coast and fairs among the Tejas. Mentioned are the Jumano, the Ervipiame, the Cibolo, and some other groups that later show up in Rancheria Grande. It's easy to misunderstand the documents - ya' almost have to diagram them sort of like we diagrammed sentences in high school English. The documents report the fairs are annual events. Documents in the book don't make clear which groups attended which fairs nor do they make clear how frequently groups attended. 
Some really thought-provoking stuff in those documents. More questions staring you in the face than ever can be answered, I'm guessing. Jim often talked about remembering to consider the north/south routes. How about routes that are both north/south and east/west as in the case of the Jumano, Ervipiame, and the travels to various fairs?

To say Mexico was in turmoil in the $17^{\text {th }}$ century is a gross understatement. Indian groups were in rebellion. Pressure from Indian groups on all sides, in Old and New Mexico.

Fr. Paredes writes about Rancheria Grande de los Ervipiames, making clear the Ervipiame were fearsome warriors. Diego Ramon had written about them as did the Rio Grande missionaries who reported a violent attack on the presidio of Coahuila (Monclova) and the Rio Grande missions. No sooner had Cortez showed up than the "thrust northward" began. That's how their actions often are described in by historians.

Think of it this way, some people we don't know show up ... it's as if the Mother Ship lands. Suddenly our grocery stores are looted and burned, they kick us off our farms and ranch lands, our hospitals are destroyed. Our cars and computers disappear and don't expect us to function without them! Oh, and there will be no church services anymore. No gumbo, no fish fries, no crayfish boils. Nothing digital. Everything we have, everything that identifies us is obliterated. We are displaced and we rebel against the "displacers".

That's a woeful attempt to explain what it might have been like in the $17^{\text {th }}$ century when native groups were forced to interact with Spaniards and other native groups they neither knew nor trusted. Nobody seemed too keen on the Apache and, later, the Comanche. That's a general statement. Spaniards feared the Apache; the Ervipiame despised the Apache, and the Spaniards. Nobody much liked anybody, really.

Spaniards continuously were on guard for Indian raids, from all directions. Oh, let's not forget Frenchmen who had a bad habit of showing up from time to time (La Salle and Jean Jari and St. Denis) and rumors of war, etc. Everywhere, everybody was on edge. The world as people knew it was changing, already had changed. All was in continuous motion, like globs in that lava lamp, but now on steroids. By the second decade of the $18^{\text {th }}$ century, hostilities were even more widespread and intense. Apaches were making their presence known more frequently, in greater force, and across a larger region. The presence of horses and French firearms was too great a temptation for the Apache. What I'll describe simply as the "western flank of Caddo country" was open to Apache invasion as were Nortenos on the Red River and groups on the Texas gulf coast.

Probably 15 years ago I found a couple of references that got my attention. They were about Caddo trade fairs and treaties, and coastal group treaties. Fr. Juan Domingo Arricivita wrote two volumes generally known as the "Apostolic Chronicle." The first four or five pages of Volume I describe the foundation of the San Xavier missons in Texas at a site between the rivers Animas and San Xavier, today recognized as the San Gabriel, at a place where the rivers joined near present Rockdale, Texas. Troops from Bejar, la Bahia and Los Adaes were sent there. Construction of the first mission began about 1745. Within a decade, the missions were abandoned. Since 1688, Spaniards had tried to missionize the Ervipiame. Each mission established included the name San Xavier; each attempt failed, of course, some sooner than others.

Arricivita wrote that the natural setting offered some protection for the Indians of Rancheria Grande and some other groups plus their families and stock against Apache raids. What I couldn't forget is that in addition to natural resources, he mentioned the site was a converging point for all the paths leading to the places where their relatives and neighbors lived. For some activities, they separated into groups, but if they needed to unite quickly for Apache wars or for some 
social reason, they would notify the others by means of smoke signals, and quickly assemble. It made me wonder whether all villages, be they Caddo, coastal, Norteno and/or the San Xavier groups, possibly were converging points for north/south and east/west routes. I'm inclined to think so "cept for some of the coastal groups when "south" would put them into the gulf.

The other reference haunted me. Couldn't find it. Finally, I put my hands on it. Was stashed in a pocket folder. It's Descriptions of Tejas or Asinai Indians, 1691 - 1722, pp. 178 and 179, Southwestern Historical Quarterly. Easy enough, huh? I remembered what the document said, but I couldn't remember who wrote it or where it was published. ARGH!!! Finding it again was like being five years old on Christmas morning. No, it was better than that!

Discussed are the purposes of fairs. Just as the cold weather is being felt, groups gather at a place which seems to be between near the Neches and Hasinai villages. There's a feast and an exchange of goods unavailable in their own villages. It's my perspective the most important thing they exchanged is fidelity. It's at the fairs treaties are made or renewed to defend each other against their enemies. Thus sayeth the article. The Caddo will be polite and welcome the Spaniards as long as they behave, but they (the Tejas groups) are most favorably inclined toward the French.

That's all well and good but how are those treaties enforced, and who does the enforcing? Are they all sizzle and no steak? No sirreee! There is mention the Tejas are "so strict in the observance of their pledges that they do not fail, even a day, in gathering together in search of the enemy."

The Texas Indians, says the document, maintain an inviolable peace with the surrounding nations. That's followed by a detailed description of a peaceful, diplomatic resolution to any problem. I was reminded of something from DeMezieres, when Jean Baptiste Brevel, Jr. was sent to the Arkansas Post to give notice about someone from that place stealing horses from the upper Caddo villages. Hmmm . . . it was a perfect example of what was described in the SHQ article. I'd paid particular attention because Brevel was my ancestor.

So I'm back to Pete's comments about Caddo trade and diplomacy. But what if things don't go as planned? Well, then, and this is my interpretation of what I've studied, there would follow something akin to excommunication. Excommunication is a brutal thing, a slow death. Nobody can give you food or shelter or protection of any sort. Nada, zip. That's the direct opposite of what you could anticipate receiving were you a neighbor in good standing as attested in the treaty you signed. Maybe an ousted group's survival means they get cozy with a former enemy. Maybe say, if a group had been to the fair and had made a treaty of alliance with the Caddo, but didn't show up for a call to make war against the Apache, for example, what happened to that group? Maybe that's when the excommunication began which might explain how some groups just disappear ... poof. Certainly it's how groups show up this year as a friend and the following year they are enemies of the Caddo. And, yes, I know about groups coalescing . . I'm talking about a whole other thing. There came a time when there had to be some pretty serious consequences for treaty violation, and that takes us back to the Ervipiame and Rancheria Grande and Ramon and St. Denis.

St. Denis's first trip to Mexico. Caddo guides. That wasn't lost on Ramon who survived longer on the front lines than any Spanish military leader I know. He was physically strong, adaptable and had his wits about him and probably brutally mean when it was necessary. Did he recognize when the odds were against him, did he know when to cut his losses, did he know how to bargain, was he willing to take risks? The evidence supports that he did.

These are my thoughts ... St. Denis's Caddo guides and the Ervipiame knew one another. For considerable time . . . since at least 1688. And they knew the Spaniards which, at the time, pretty much meant they knew Diego Ramon. Conversely, if you claimed to know the French, it meant you were talking about St. Denis. 
This is one of those times, when you cannot look to the documents for all the answers. What ya' do is look at the rest of the story. That categorically does not mean you fill in the gaps with fiction. Shame on anybody who does that. It means looking at the historic record and the evidence and considering those from every angle available to you. I did that and two things persuade me that Ramon and St. Denis cut a deal on the Rio Grande. St. Denis couldn't protect Ramon from the Apaches, but maybe he could divert some of them which would minimize Ramon's risk, and certainly he could take the Ervipiame and the other groups of Rancheria Grande off Ramon's hands which made the missionaries happy. That's all assuming that first the Caddo agreed to new neighbors, and, second, the Ervipiame agreed. St. Denis's guides were Hasinai so the relocation provided another layer of protection from Apaches who might show up. With no pomp and circumstance, the relocation to Caddo country occurs, without a whisper. Rancheria Grande moved. Period. Paragraph. Their "welcome to the neighborhood" gifts were French firearms. Always handy when an enemy gets rowdy.

Everybody got their needs met. When St. Denis and his guides left the Ramon expedition, I'm betting the Frenchman headed for Rancheria Grande to inform those groups and then on east for more announcements. It was the Caddo way of doing things. As for the Tejas, it's a term variously applied. Typically, it's thought to refer to the Hasinai, and sometimes it definitely does. There seems to be an expanded application referring to those groups allied to the Caddo by treaties. So, whoever wrote, "they must have been Apaches," knew what they were talking about. Nobody but an Apache would attack a Caddo, nor would anyone except an enemy of the Caddo attack a Tejas, in the larger sense.

When that Rio Grande deal was crafted, neither Ramon nor St. Denis was concerned about being "king of the mountain." They cut a deal that needed "cutting". About this "king of the mountain business," that's a European thing. My conclusions surprised me ... my research showed the kings of the mountain were the Caddo. Imagine that?! There were other kings of the mountain ... Rancheria Grande had its own time on the mountaintop, and the Nortenos. All the Tejas groups needed help. Time came when Diego Ramon needed help, St. Denis needed help, Caddo, the Nortenos, Rancheria Grande - they all needed help. They needed each other's help.

I'm not suggesting Ervipiame raids on the Rio Grande Spanish ceased altogether. I just haven't read anything about them if they did occur, and I've been looking for a long, long time. The Hasinai and the Neches had new neighbors to the west which was really helpful when Comanches started showing up. French firearms and ammunition made available to all the Tejas groups for hunting two or four legged creatures, and St. Denis brought Spaniards to his doorstep to trade. Oh, Ramon and St. Denis weren't the only parties to that "Rio Grande deal." The Caddo participated as did Rancheria Grande - it couldn't work any other way. Caddo approval was the first order of business. Without their consent to Rancheria Grande's relocation to the territory immediately west of Hasinai country, there would be no deal. The Caddo and other Tejas groups didn't forget nor did Rancheria Grande forget St. Denis's demonstrations of fidelity. Those demonstrations were the "outward and visable sign" of his loyalty to the Rio Grande deal and the parties involved.

St. Denis made a second trip to Mexico, a trip complicated by Europe's War of the Quadruple Alliance and St. Denis's fortuitous escape from a Mexican prison. Also, in Mexico, there was an order to remove Ramon from his Rio Grande command. The man had his enemies, mostly people who envied him. Ramon died in 1719 before he was removed from command.

Every now and again somebody will ask, "who are the historical figures you most would like to meet"? For me, hands down, it's St. Denis's two 1714 Hasinai guides to the Rio Grande, an Ervipiame chief of Rancheria Grande, St. Denis himself and the elder Diego Ramon. 
I've written a bit about St. Denis and researched several bits more. Much of what I found written about him flat didn't happen or the facts were woefully embellished. I've done the research to support that perspective. The same is true regarding Diego Ramon. Who knows, when you least expect it, you might receive another letter or two.

Again, Happy New Year.

Patty 